ORIGINAL ARTICLE

\title{
Subdose of human chorionic gonadotropin applied at the Hou Hai acupoint on follicular dynamics and luteal development in donkeys
}

Márcio de Oliveira Ribeiro ${ }^{1}$ (D), Rodrigo Freitas Bittencourt² (D), Marcus Antônio Rossi Feliciano ${ }^{1}$ (D), Ana Lúcia Almeida Santana ${ }^{1}$ (D), Mariana Alves de Andrade Silva ${ }^{2}$ (D), Morgana Duarte Felix ${ }^{2}$ (D), Larissa Rodrigues Santana² (D), Larissa Pires Barbosa1* (D)

${ }^{1}$ Universidade Federal do Recôncavo da Bahia, Centro de Ciências Agrárias, Ambientais e Biológicas, Cruz das Almas, BA, Brasil ${ }^{2}$ Universidade Federal da Bahia, Escola de Medicina Veterinária e Zootecnia, Salvador, BA, Brasil

How to cite: Ribeiro MO, Bittencourt RF, Feliciano MAR, Santana ALA, Silva MAA, Felix MD, Santana LR, Barbosa LP. Subdose of human chorionic gonadotropin applied at the hou hai acupoint on follicular dynamics and luteal development in donkeys. Anim Reprod. 2020;17(4):e20200554. DOI: https://doi.org/10.1590/1984-3143AR2020-0554

\begin{abstract}
The objective of this study was to evaluate the effects of an hCG subdose applied at the Hou Hai acupoint as an ovulation inducer in donkeys. Eleven donkeys were distributed in randomized blocks in $\mathrm{T} 1=$ application of 1,500 IU of hCG intravenous (IV); T2 $=450$ IU of hCG applied at the false acupoint (IV), and T3 $=450$ IU of hCG applied at the Hou Hai acupoint. There was no difference $(P>0.05)$ between the treatments regarding the mean diameter of the pre-ovulatory follicle $(34.5 \pm 1.3 \mathrm{~mm})$, the ovulation rate $(96.97 \%)$, the interval between induction and ovulation $(58.07 \pm 16.82 \mathrm{~h}$ ), the mean diameter of the $C L(D 0=23.0 \pm 0.6$; $D 2=27.7 \pm 1.9$ and $\mathrm{D} 8=28.2 \pm 0.8 \mathrm{~mm})$, and serum $\mathrm{P}_{4}$ concentrations $\left(10.50 \pm 2.99 \mathrm{ng} \cdot \mathrm{mL}^{-1}\right)$. The application of $450 \mathrm{IU}$ of hCG at the Hou Hai acupoint increased ovulation rate $(72.73 \%)$ more than $48 \mathrm{~h}$ after induction $(P=0.03)$ and a larger diameter of the $C L$ on $D 4(30.7 \pm 5.1 \mathrm{~mm})(P=0.04)$. The vascularization area of the $C L$ on $D 8$, obtained by minimum number of colored pixel (NCP), was greater $(P<0.05)$ in the donkeys that received 1,500 IU of IV hCG $(T 1,41.91 \pm 1.17)$, and we found a positive correlation $(P<0.05)$ between mean NCP and $P_{4}$ concentration in the donkeys that received 450 IU of hCG IV at the false acupoint (T2) or at the Hou Hai acupoint (T3). The application of 450 IU of hCG by IV route at the false acupoint or the Hou Hai acupoint was sufficient to induce ovulation in donkeys, demonstrating that the average dosage commonly used for this species is too high.
\end{abstract}

Keywords: acupuncture, donkey, doppler, progesterone, pêga race.

\section{Introduction}

Because they are rustic animals and adapted to semi-arid regions, donkeys are often used in agricultural work, which is perhaps the most important role played by donkeys. However, few studies have been carried out to elucidate the reproductive physiology of this species, which is mistakenly compared to that of equines (Taberner et al., 2008; Tadesse and Tefera, 2013). As such, some researchers have focused specifically on the physiological aspects of the reproductive cycle of donkeys, especially after the development of conservation programs aimed at endangered races of donkeys and populations at risk of extinction (Mariante and Egito, 2002; Galisteo and Perez-Marin, 2010).

As with the equine species, human chorionic gonadotropin (hCG) is used in donkeys as an ovulation inducer, because it is similar to luteinizing hormone (LH) (Wilson et al., 1990) and because it can promote an ovulation rate as high as $100 \%$ up to 48 hours after application (Awan et al., 2016), as well as elevating progesterone $\left(P_{4}\right)$ production after ovulation

*Corresponding author: larissa@ufrb.edu.br

Received: September 04, 2020. Accepted: October 27, 2020

Financial support: None.

Conflict of interest: The authors have no conflict of interest to declare.

(c) (i) Copyright ( $\odot$ The Author(s). This is an Open Access article distributed under the terms of the Creative Commons Attribution License, which permits unrestricted use, distribution, and reproduction in any medium, provided the original work is properly cited. 
(Kohne et al., 2014). However, hCG is commonly applied intravenously (IV), intramuscularly (IM), or subcutaneously (SC) (Romano et al., 2015), and the dose used in protocols for donkey species is the same as that indicated by the manufacturers for mares.

An alternative route for hormonal application is pharmacopuncture, which enables the use of reduced doses and has similar results to those obtained using conventional doses (Luna et al., 2008; Souza et al., 2019; Cardoso et al., 2018). Pharmacopunture also reduces undesirable side effects, sediments in animal products for consumption, and treatment costs (Wynn et al., 2001), thus enabling successive applications during the breeding season (Gastal et al., 2006). The Hou Hai acupoint, also known as Chang Qiang (Governing Vessel 1 - GV1), has a sedative indication (Luna et al., 2008), and is one of the points that is linked to the reproductive organs, as well as being easily accessible (Wang et al., 2007), making it viable to apply hCG to this acupoint in the field.

However, studies on the use of acupoints and reduced doses of hormones in ovulation induction protocols are still rare, especially in donkey species, as previously discussed. Thus, the goal of this study was to evaluate the effectiveness of subdoses of hCG administered at the Hou Hai acupoint as an ovulation inducer in donkeys.

\section{Material and methods}

\section{Study location and ethical approval}

The study was performed at the Experimental Farm of the School of Veterinary Medicine and Animal Science of the Federal University of Bahia (EMVZ/UFBA), in the city of Entre RiosBA, located at a latitude of $11^{\circ} 56^{\prime} 31^{\prime \prime}$ south, a longitude of $38^{\circ} 05^{\prime} 04^{\prime \prime}$ west, and an altitude of 152 meters above sea level. The climate is tropical, with a dry season in the summer, according to the Köppen-Geiger climatic classification. The average annual rainfall is $1,550 \mathrm{~mm}$, and the mean temperature is $24.0^{\circ} \mathrm{C}$, with a minimum of $16.8^{\circ} \mathrm{C}$ and a maximum of $32.5^{\circ} \mathrm{C}$.

The project was approved by the Ethics Committee on Animal Use (CEUA) of EMVZ / UFBA, under registry $n^{\circ} 67 / 2016$

\section{Animals and experimental design}

Eleven reproductively active female donkeys of the Pêga breed were used in this study. All donkeys were considered healthy after physical and obstetric examination, and their body condition score ranged between 4 and 6 . The donkeys were used in three periods, distributed in randomized block crossover designs, with the period used as the blocking factor. There were three treatments, as follows: T1: 1,500 IU of hCG (Chorulon, MSD, Brazil, 100\% dosage) applied intravenously (IV) in the jugular vein; T2: 450 IU of hCG (30\% dosage) applied IV in the jugular vein; and T3: 450 IU of hCG (30\% dosage) applied at the Hou Hai acupoint. There were a total of 11 replicates per treatment, and each donkey was considered an experimental unit.

\section{Ovulation inducer protocol}

All donkeys were monitored every $48 \mathrm{~h}$ using mode-B ultrasonographic (US) examination. The first ovulation of the reproductive season was not included in the study to avoid the transition phase, and we confirmed the reestablishment of reproductive activity in the mating season. Eight days after the first ovulation, $5 \mathrm{mg}$ of dinoprost tromethamine (Lutalyse, Pfizer, USA) was administrated to all donkeys by IM route, as a luteolytic agent, followed by daily monitoring of follicular development by B-mode US examination. When a dominant follicle presented with a diameter $\geq 30 \mathrm{~mm}$ and we observed the presence of grade 3 uterine edema, ultrasound examination of the pre-ovulatory follicle was performed in color Doppler mode to evaluate perifollicular vascularization. Ovulation was induced with hCG, using the dose and route of each specific treatment. 
Previous antisepsis was performed on IV hCG applications in the jugular and Hou Hai acupoint with $70 \%$ alcohol. For applications in the Hou Hai acupoint, located in the depression between the average distance from the base of the tail (coccygeal muscle) to the anal sphincter with innervation in the caudal rectal nerve, a $1 \mathrm{~mL}$ syringe was used, coupled to a $16 \mathrm{G}$ catheter, inserted in an angular position of $45^{\circ}$, with a $45 \mathrm{~mm}$ depth (catheter's size) (Hwang and Limehouse, 2006).

\section{Evaluated variables}

The variables evaluated in this study were: mean diameter (mean of the larger horizontal measure and the larger vertical measure) and vascularization (number of colored of minimum, maximum, and mean, and heterogeneity) of the pre-ovulatory follicle and $\mathrm{CL}$ on days 0 (D0), 2 (D2), 4 (D4), and 8 (D8); ovulation rate in the first $48 \mathrm{~h}$ after induction; interval between induction and ovulation; ovulation rate at $48 \mathrm{~h}$ after induction; serum concentration of $\mathrm{P}_{4}$ on D8; and the correlation between mean $\mathrm{CL}$ diameter, $\mathrm{P}_{4}$ concentration, and blood flow of the pre-ovulatory and $\mathrm{CL}$ follicles.

After the ovulation inducer was applied, B-mode ultrasonography evaluations were performed twice a day, at 12-h intervals, until the approximate time of ovulation, which is associated with the disappearance of the follicle image (anechoic) and replacement by the image of the $\mathrm{CL}$ (hypoechogenic). To follow $\mathrm{CL}$ development, measurements of the mean diameter in B-mode and Doppler vascularization were performed on D0 (day of ovulation); D2; D4, and D8. A color Doppler ultrasonography device (Mindray Z5, model DP 2200 VET, China) coupled to a linear transrectal transducer $(5.0 \mathrm{~Hz}$ ) was used to assess blood perfusion (follicular and luteal vascularization), visualizing color changes corresponding to blood flow throughout the follicular wall and luteal parenchyma.

The pre-ovulatory follicle and CL images obtained by color Doppler US were analyzed using Image ProPlus software (Media Cybernetics Inc., San Diego, California, USA) at the Laboratory of Ultrasonography of the Animal Reproduction Sector of the Faculty of Agrarian and Veterinary Sciences of the Paulista State University "Júlio de Mesquita Filho". A tool within the software was used to circumvent the vascularized areas of the pre-ovulatory follicle and CL in order to obtain the average number of colored pixel [NCPs; ecotextures data, pixel heterogeneity (standard deviation NCPs)], as well as minimum and maximum NCPs.

Serum $\mathrm{P}_{4}$ concentrations were obtained from blood samples collected by jugular vein puncture, using tubes for vacuum collection without anticoagulant, eight days after ovulation. After collection, the blood was centrifuged ( $300 \times \mathrm{g}$ for 15 minutes) to obtain the serum, which was transferred to polypropylene microtubes with a capacity of $2 \mathrm{~mL}$. Samples were labelled, stored at $-20{ }^{\circ} \mathrm{C}$, and sent for analysis to the Animal Reproduction Laboratory of the Department of Animal Science of the Federal University of Viçosa. The chemiluminescence method was used with a commercial kit (Access Progesterone, Beckman Coulter, California, USA) for $\mathrm{P}_{4}$ concentrations, following the manufacturer's guidelines.

\section{Statistical analyses}

The data were evaluated for normality using the Shapiro-Wilk test, followed by variance analysis, and Tukey test for the parametric data (mean diameter and follicle vascularization at the moment of induction, interval between inducer application and ovulation, mean diameter, and $C L$ vascularization on D0, D2, D4, and D8). We used the Kruskal-Wallis test for nonparametric data (ovulation rate before and after 48 hours of inducer application). To evaluate correlations between mean $\mathrm{CL}$ diameter, serum $\mathrm{P}_{4}$ concentrations, and pre-ovulatory follicle and $\mathrm{CL}$ blood flow on the eighth day (D8) after ovulation, we used Pearson's correlation. Differences were considered significant at $\mathrm{P}<0.05$. 


\section{Results}

The three protocols used did not have an effect on the pre-ovulatory follicle diameter, ovulation rate, or the interval between inducer application and ovulation $(P>0.05)$, but did have an effect on the ovulation rate more than $48 \mathrm{~h}$ after induction $(P=0.03)$ (Table 1$)$. Donkeys submitted to the protocol using 450 IU hCG applied at the Hou Hai acupoint (T3) had a higher ovulation rate $(72.73 \%$ ) more than $48 \mathrm{~h}$ after induction, which means, only $27.27 \%$ of ovulations occurred in the first $48 \mathrm{~h}$ after induction.

Table 1. Pre-ovulatory follicle, ovulation rate and moment of ovulation of the donkey with ovulation induced by subdose of the human chorionic gonadotropin in Hou Hai acupoint

\begin{tabular}{ccccc} 
Variables & T1 $(\mathbf{n = 1 1})^{\mathbf{1}}$ & T2 $(\mathbf{n = 1 1})^{\mathbf{2}}$ & T3 $(\mathbf{n = 1 1})^{\mathbf{3}}$ & P value \\
\hline Diameter pre-ovulatory follicle $(\mathrm{mm})^{4}$ & $34.6 \pm 4.6$ & $35.9 \pm 3.0$ & $33.2 \pm 41$ & 0.318 \\
\hline Ovulation rate $(\%)^{5}$ & 100.00 & 90.91 & 100.00 & 0.368 \\
\hline Interval inducter and ovulation $(\mathrm{h})^{4}$ & $50.0 \pm 39.9$ & $46.8 \pm 21.5$ & $77.4 \pm 28.0$ & 0.058 \\
\hline Ovulation above 48h after induction $(\%)^{5}$ & $18.18^{\mathrm{a}}$ & $36.36^{\mathrm{ab}}$ & $\mathbf{7 2 . 7 3 ^ { \mathrm { b } }}$ & 0.034 \\
\hline
\end{tabular}

${ }^{1} \mathrm{~T} 1=1500 \mathrm{IU}$ of hCG IV. ${ }^{2} \mathrm{~T} 2=450 \mathrm{IU}$ of hCG IV. ${ }^{3} \mathrm{~T} 3=450 \mathrm{IU}$ of hCG of Hou Hai acupoint. ${ }^{4}$ Parametric data, refer to the mean \pm standard deviation and were not influenced by the treatments, ANOVA $(P>0.05) .{ }^{5}$ Non-parametric data. ab There was difference by the Kruskal Wallis test $(P<0.05)$.

The use of a subdose of hCG administered at either the false acupoint or the Hou Hai acupoint did not affect $(P>0.05)$ the mean diameter of the $C L$ on days D0, D2, and D8. Similarly, the serum concentration of $\mathrm{P}_{4}$ eight days after ovulation was not affected by the induction protocols used $(P>0.05)$ (Table 2$)$, but the protocols did affect the $C L$ diameter on $D 4(P=0.04)$. Donkeys administered $450 \mathrm{IU}$ of hCG at the Hou Hai acupoint (T3) had a larger CL diameter, which was similar to that of donkeys administered 450 IU (IV) in the false acupoint (T2), but higher than that of donkeys receiving the full dose of hCG by IV (Table 2). This suggests that commonly used doses for ovulation induction in donkeys are possibly too high.

Table 2. Development of the corpus luteum and serum progesterone concentration of donkey with ovulation induced by subdoses of human chorionic gonadotrophin in Hou Hai acupoint

\begin{tabular}{ccccc} 
Variables & T1 $(\mathbf{n}=\mathbf{1 1})^{\mathbf{1}}$ & T2 $(\mathbf{n = 1 1})^{\mathbf{2}}$ & T3 $\left(\mathbf{n = 1 1 ) ^ { 3 }}\right.$ & P value \\
\hline Corpus luteum on ovulation day (cm) & $22.4 \pm 7.3$ & $23.3 \pm 4.9$ & $23.4 \pm 4.8$ & 0.91 \\
\hline Corpus luteum 2d after ovulation (cm) & $25.9 \pm 5.2$ & $27.6 \pm 3.7$ & $29.6 \pm 5.4$ & 0.21 \\
\hline Corpus luteum 4d after ovulation (cm) & $25.8 \pm 4.4^{\mathrm{a}}$ & $27.0 \pm 4.5^{\mathrm{ab}}$ & $30.7 \pm 5.1^{\mathrm{b}}$ & 0.04 \\
\hline Corpus luteum 8d after ovulation (cm) & $27.3 \pm 2.4$ & $28.8 \pm 4.7$ & $28.5 \pm 3.1$ & 0.54 \\
\hline Progesterone concentration 8d $(\mathrm{ng} / \mathrm{mL})$ & $7.65 \pm 7.11$ & $10.22 \pm 9.45$ & $13.63 \pm 11.12$ & 0.32 \\
\hline
\end{tabular}

${ }^{1} \mathrm{~T} 1=1500 \mathrm{IU}$ of hCG IV. ${ }^{2} \mathrm{~T} 2=450 \mathrm{IU}$ of hCG IV. ${ }^{3} \mathrm{~T} 3=450 \mathrm{IU}$ of hCG of Hou Hai acupoint. The data refer to the mean \pm standard deviation. ab Different letters overwritten in the same line differ $(P=0.046)$ for the Tukey test

The administration of 1,500 IU of hCG IV (T1) resulted in higher blood perfusion of the CL on D8, as assessed by the minimum NCP $(P<0.05)$ (Figure 1a). However, the mean, maximum, and heterogeneity of number of colored pixel were similar between treatments for both the pre-ovulatory follicle and $C L$ on $D 0, D 2, D 4$, and $D 8(P>0.05)$, indicating that there was no significant effect of the hCG dose used, nor of the route of application (Figure 1b, c, d). 
(a)

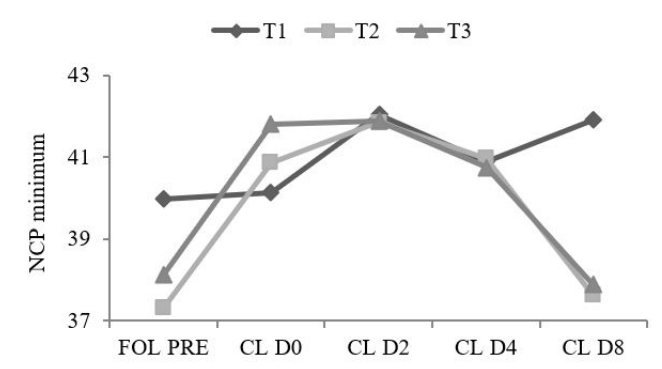

(c)

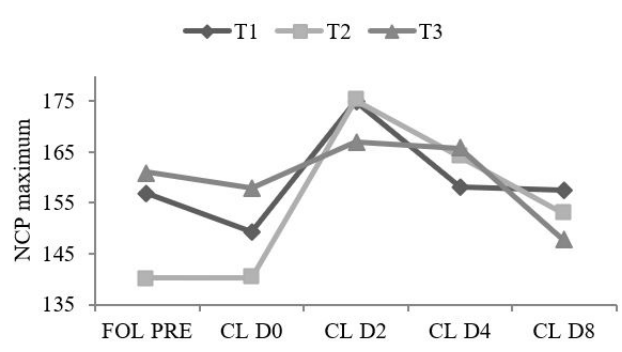

(b)

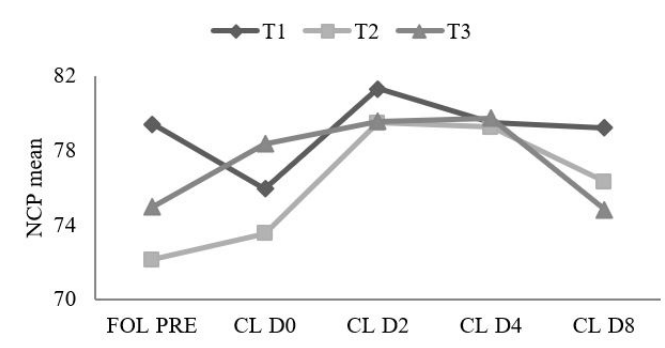

(d)

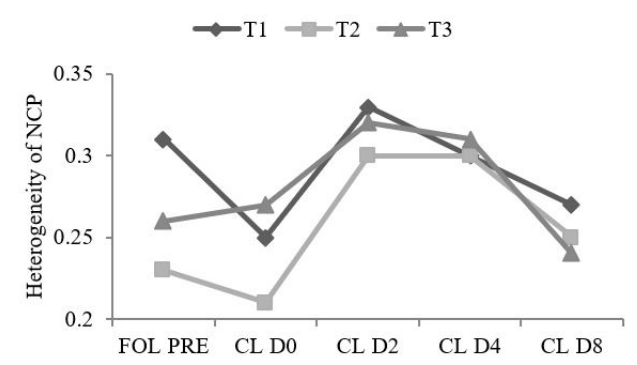

Figure 1. Minimum (a), medium (b), maximum (c) and heterogeneity (d) of the number of colored pixel (NCP) of the pre-ovulatory follicle (FOL PRE) and corpus luteum (CL) on days 0 (D0), 2 (D2), 4 (D4) and 8 (D8) after ovulation. T1 = 1,500 IU of hCG IV; T2 = 450 IU of hCG IV; T3 = 450 IU of hCG in Hou Hai acupoint. There was a statistical difference for CL D4 by the Tukey test $(P<0.05)(a)$. There was no difference between treatments for FOL PRE; CL D0; CL D2 and CL D4, ANOVA (P > 0.05) (b, c, d).

For donkeys receiving subdoses of hCG (450 IU) both at the false acupoint and the Hou Hai acupoint, a positive correlation was found between mean NCP and $\mathrm{P}_{4}$ concentration on D8 $(P<0.05)$. However, there was no correlation between the same variables for the donkeys that received the full dose of hCG (1,500 IUI) by IV (T1), nor between the size of the CL and the concentration of $\mathrm{P}_{4}$. That is, the behavior of one of these variables did not influence the behavior of the other $(P>0.05)$.

\section{Discussion}

The treatments resulted in similar patterns in the pre-ovulatory follicle diameter, ovulation rate, and the interval between induction and ovulation, indicating that the dose of $450 \mathrm{IU}$ administered intravenously at the false acupoint, or at the Hou Hai acupoint can be used to induce ovulation in donkeys (Table 1). When using $450 \mathrm{IU}$ of hCG, the mean diameter of the pre-ovulatory follicle was $34.5 \mathrm{~mm}$, which is within the predicted range for the species, which may vary between 34 and $45 \mathrm{~mm}$, for either induced or natural ovulation. Derar and Hussein (2011) obtained a mean diameter of $36 \mathrm{~mm}$ when evaluating follicular dynamics of donkeys during the estrous cycle, with spontaneous ovulation. Carluccio et al. (2007) previously obtained a mean diameter of the pre-ovulatory follicle of $38 \mathrm{~mm}$ by inducing ovulation of follicles with a diameter between 30 and $35 \mathrm{~mm}$ with 2,500 IU of hCG, which is a higher dose than that used in the present study.

Quaresma and Payan-Carreira (2015) reported a mean follicle diameter of $40.2 \mathrm{~mm}$ in single ovulations, $36.7 \mathrm{~mm}$ in double ovulations, and $38.6 \mathrm{~mm}$ in triple ovulations, when characterizing the estrous cycle of donkeys. This was similar to the results of Carluccio et al. (2017), who obtained pre-ovulatory follicle diameter of up to $45.1 \mathrm{~mm}$ in postpartum estrous cycles for this species, without using an ovulation inducer. Both studies found higher mean follicle diameter values than the one obtained in the present study. However, it is worth 
mentioning that in mares, the application of hCG anticipates the ovulation of pre-ovulatory follicles, which usually have a smaller diameter than follicles resulting from spontaneous ovulations, as hCG accelerates follicular maturation and ovulation, as described by CuervoArango and Newcombe (2008). The same is likely the case in donkeys, since hCG acts in the same way, independent of the species.

The use of hCG as an ovulation inducer promotes high ovulation rates, as demonstrated in the present study (Table 1), and in previous studies using higher doses of hCG in the same species (Carluccio et al., 2007) or in mares (Morel et al., 2010). The objective of induction is the prediction of the time of ovulation, and therefore differences between the experimental groups regarding the time interval between induction and ovulation were also considered in this study. We found no significant effect of our treatments, although hCG appeared to meet this criterion better. According to Samper (2008), the mean response time to hCG is around 36 hours, ranging from 12 to $48 \mathrm{~h}$ when using doses between 1,500 to 3,300 IU IM or IV.

In fact, in the present study, most ovulations (81.82\%) in donkeys that received 1,500 IU of hCG IV (T1) occurred before $48 \mathrm{~h}(\mathrm{P}<0.05)$. However, in the donkeys that received $450 \mathrm{IU}$ at the Hou Hai acupoint (T3), despite having a $100 \%$ ovulation rate, only $27.27 \%$ of ovulations occurred during the first $48 \mathrm{~h}$ after induction (Table 1). This result differs from that found by Carluccio et al. (2007), who found that $91.7 \%$ of predicted ovulations occurred within the first 48 hours after induction, although these authors administered a higher hCG dose (2,500 IU).

The protocols used in the present study were effective for inducing ovulation, but should be used when using natural mating or artificial insemination with fresh semen, due to the greater sperm viability in the reproductive tract of donkeys. The alternative for using cooled semen would be to perform hCG treatment 12-24 h after detection of follicles that are $\geq 30 \mathrm{~mm}$ in size.

The use of a subdose of hCG at the false acupoint (IV) or Hou Hai acupoint as an ovulation inducer was as effective in promoting the development of the CL as the dose of 1,500 IU applied by the IV route, as demonstrated by the diameter of the CL obtained from the day of ovulation (D0) to D8, as well as by serum $\mathrm{P}_{4}$ concentrations (Table 2). In addition, donkeys treated with 450 IU of hCG at the Hou Hai acupoint had the largest diameter of CL on D4 $(P=0.04)$, which may have been caused by the longer interval between induction and ovulation, which may have resulted in larger follicles and consequently the corresponding formation of larger CL.

The maximum $C L$ diameter found in donkeys was $30.7 \pm 5.1 \mathrm{~mm}$ on D4, which differs from the results reported by Conceição et al. (2009), who found a maximum diameter of $26.2 \pm 4.4 \mathrm{~mm}$ on D5 for simple ovulations following the luteal development of donkeys. Derar and Hussein (2011), when evaluating the estrous cycle of donkeys, reported a maximum $\mathrm{CL}$ diameter of $26.77 \pm 1.28 \mathrm{~mm}$ on D13, with the CL regressing until D17. These results demonstrate the efficiency of the use of subdoses of hCG in the ovulation protocol applied at the Hou Hai acupoint in donkeys, as well as for promoting the adequate development of $\mathrm{CL}$ when compared to $\mathrm{CL}$ formed from spontaneous ovulations, and those formed from induced ovulations with a higher dose of IV hCG (1,500 IU).

The concentration of $\mathrm{P}_{4}$ on the eighth day after ovulation was similar between treatments, and similar to results obtained by Carluccio et al. (2008), who evaluated 22 donkeys, and reported a mean serum $\mathrm{P}_{4}$ concentration of $9.1 \mathrm{ng} \cdot \mathrm{mL}^{-1}$. This indicates the possible functionality of CL, since, according to Grizendi and Fernandes (2015) and Sieme et al. (2016), $\mathrm{P}_{4}$ concentrations below $2 \mathrm{ng} \cdot \mathrm{mL}^{-1}$ are characteristic of luteal insufficiency in mares and donkeys. In this study, we obtained serum $\mathrm{P}_{4}$ concentrations below $2 \mathrm{ng} \cdot \mathrm{mL}^{-1}$ in four donkeys, and serum $\mathrm{P}_{4}$ concentrations below $1 \mathrm{ng} \cdot \mathrm{mL}^{-1}$ in only one donkey. This is not uncommon, and, according to Conceição et al. (2009), $\mathrm{P}_{4}$ concentrations below $1 \mathrm{ng} \cdot \mathrm{mL}^{-1}$ are characteristic of the estrogenic phase. These results suggest that, considering only progesterone production, $15.15 \%$ of the donkeys evaluated had non-functional CL.

However, evaluation of $\mathrm{CL}$ diameter and $\mathrm{P}_{4}$ concentration alone does not allow the determination of CL functionality (Carluccio et al., 2008), although some studies indicate that the larger the diameter, the higher the hormone production (in this case, $\mathrm{P}_{4}$ ). To determine $\mathrm{CL}$ functionality, it is necessary to associate the echogenicity and blood perfusion characteristics 
of $\mathrm{CL}$, and the serum $\mathrm{P}_{4}$ concentration, since the vascularization of the $C L$ and the serum $\mathrm{P}_{4}$ concentration increase in the days after ovulation, thus enabling the prediction of the $\mathrm{CL}$ functionality.

Thus, in this study, we evaluated the vascularization of the ovarian structures, the preovulatory follicle, and the $\mathrm{CL}$, using the average, maximum, and minimum number of colored pixel (NCP), as well as the NCP heterogeneity, obtained by Doppler ultrasound examinations. According to Díaz-Duran et al. (2017), after ovulation, neovascularization is essential to draw substrates to the luteal cells, which are responsible for the production and subsequent secretion of $\mathrm{P}_{4}$. As such, it is important to use methods that make the evaluation of $\mathrm{CL}$ vascularization more objective, as such methods tend to improve the results of the reproductive biotechniques used.

There was a significant effect of treatments on CL tissue changes between D4 and D8 regarding the minimum number of pixels $(P<0.05)$. The donkeys receiving $1,500 \mathrm{IU}$ of IV hCG (T1) had a higher minimum NCP (Figure 1a). However, the same patterns were observed regarding theaf mean and maximum NCPS, and for the NCP heterogeneity in the three treatments $(P>0.05)$ (Figure $1 b, c, d)$, with values reduced from the pre-ovulatory follicle and $\mathrm{CL}$ on D0. Maximum values were obtained on D2, which decreased until D8, indicating that the therapy used in the present study did not improve luteal blood flow, regardless of dose or route of application.

The results of the present study corroborate those of Romano et al. (2015), who evaluated the hemodynamics of mares treated with hCG and did not find a significant effect of hCG treatment. These authors concluded that the use of hCG as an ovulation inducer does not affect the serum concentration of $\mathrm{P}_{4}$ in either donkeys or mares. However, Gastal et al. (2006) reported a progressive increase in follicular vascularization at the time of ovulation induction after hCG treatment, with a sudden reduction in the four hours before ovulation, detected at one-hour intervals. The divergence between the results obtained in these studies suggests that other studies on the hemodynamics of the pre-ovulatory follicle and CL of donkeys, treated with an ovulation inducer or not, should be performed. Such studies will contribute to our understanding of the reproductive physiology of the species.

The results of this study demonstrate that, in addition to the possibility of evaluating the $\mathrm{CL}$ activity through its diameter and $\mathrm{P}_{4}$ production, it is possible to study the development of the follicle echographically from the development of the follicle to the formation of $C L$ in the ovarian tissue, and to correlate these with the endometrial modifications. This allows us identify what would be a normal CL, associating its morphology and function. In this study, when evaluating the association between $C L$ diameter, $\mathrm{P}_{4}$ concentration, and NCP, a positive correlation was found only between the mean NCP and $\mathrm{P}_{4}$ concentration on D8 in donkeys receiving $\mathrm{hCG}$, regardless of the application route. Studies using mares also found a positive correlation between blood flow and $\mathrm{P}_{4}$ concentration (Ginther et al., 2007) although studies using Doppler ultrasonography for evaluation in donkey species are rare.

Although some studies found a positive correlation between $\mathrm{CL}$ size and serum $\mathrm{P}_{4}$ concentration (Arruda et al., 2001), in the present study, there was no correlation between these variables. That is, the increase in $\mathrm{CL}$ area did not have an effect on $\mathrm{P}_{4}$ concentration in the bloodstream. This was also found by Rodrigues et al., (2014), who reported that, in their study, the correlation between these variables was non-existent. As Nagy et al. (2004) point out, other individual factors may affect $\mathrm{P}_{4}$ concentrations, such as weight, age, metabolism and amount of hormone receptors.

\section{Conclusion}

The association of $\mathrm{CL}$ diameter with $\mathrm{P}_{4}$ concentration and tissue changes in NCP allows us to infer that the $C L$ formed were functional and capable of maintaining gestation, regardless of the dose of hCG used and the route of application. This is a noteworthy result, since the use of subdoses of hCG to induce ovulation makes it possible to reduce the cost of the protocol, and reduces the risks of anti-hCG antibody formation, in addition to promoting ovulation 
effectively. The use of Doppler ultrasonography is pertinent, because this makes it possible to predict the functionality of $\mathrm{CL}$ in real time based on their blood flow, which may be associated with the diameter.

\section{References}

Arruda RP, Visintin JA, Fleury JJ, Garcia AR, Madureira EH, Celeghini ECC, Neves Neto JR. Existem relações entre tamanho e morfoecogenecidade do corpo lúteo detectados pela ultra-som e os teores de progesterona plasmática em receptoras de embriões equinos? Braz J Vet Res Anim Sci. 2001;38(5):233-9. http://dx.doi.org/10.1590/S1413-95962001000500007.

Awan FS, Mehmood MU, Sattar A, Ahmad N. Comparative efficacy of hCG or GnRH analogue (lecirelin acetate) on follicular dynamics, degree of endometrial edema, sexual behavior, ovulation and pregnancy rate in crossbred broodmares. J Equine Vet Sci. 2016;41:71-2. http://dx.doi.org/10.1016/j.jevs.2016.04.062.

Cardoso RC, Barbosa LP, Souza RS, França CS, Ribeiro MDM Jr, Santana ALA, Jesus RDL, Santos RS. Application of hormonal subdoses at acupoint Hou Hai in estrus synchronization protocols of goats. Semina. Ciênc Agr. 2018;39(3):1135-42. http://dx.doi.org/10.5433/1679-0359.2018v39n3p1135.

Carluccio A, Panzani S, Tosi U, Faustini M, De Amicis I, Veronesi MC. Efficacy of hCG and GnRH for inducing ovulation in the jenny. Theriogenology. 2007;68(6):914-9. http://dx.doi.org/10.1016/j.theriogenology.2007.07.005. PMid:17716724.

Carluccio A, Panzani S, Contri A, Tosi U, De Amicis I, Veronesi MC. Luteal function in jennies following PGF2a treatment 3 days after ovulation. Theriogenology. 2008;70(1):121-5. http://dx.doi.org/10.1016/j.theriogenology.2008.03.010. PMid:18439666.

Carluccio A, Gloria A, Robbe D, Veronesi MC, De Amicis I, Cairoli F, Contri A. Reproductive characteristics of foal heat in female donkeys. Animal. 2017;11(3):461-5. http://dx.doi.org/10.1017/S175173111600183X. PMid:27571706.

Conceição JC, Freitas LM No, Aguiar CR Fo, Araújo GHM, Oliveira JV, Bartolomeu CC, Oba E, Meira C. Concentração plasmática de progesterona durante o ciclo estral de Jumentas (Equus asinus) com ovulações simples e duplas. Med Vet. 2009;3(3):15-9.

Cuervo-Arango J, Newcombe JR. Repeatability of preovulatory follicular diameter and uterine edema pattern in two consecutive cycles in the mare and how they are influenced by ovulation inductors. Theriogenology. 2008;69(6):681-7. http://dx.doi.org/10.1016/j.theriogenology.2007.11.019. PMid:18242672.

Derar Rl, Hussein HA. Ovarian follicular dynamics during the estrous cycle in jennies in upper egypt. Vet Med Int. 2011;1:1-6. http://dx.doi.org/10.4061/2011/860518. PMid:21647342.

Díaz-Duran M, Zarco L, Boeta AM. Ovarian dynamics and estrous cycle length in the donkey (Equus asinus). Theriogenology. 2017;103:1-8. http://dx.doi.org/10.1016/j.theriogenology.2017.07.003. PMid:28763724.

Galisteo J, Perez-Marin CC. Factors affecting gestation length and estrus cycle characteristics in Spanish donkey breeds reared in southern Spain. Theriogenology. 2010;74(3):443-50. http://dx.doi.org/10.1016/j.theriogenology.2010.02.027. PMid:20451997.

Gastal EL, Gastal MO, Ginther OJ. Relationships of changes in B-mode echotexture and colour-Doppler signals in the wall of the preovulatory follicle to changes in systemic oestradiol concentrations and the effects of human chorionic gonadotrophin in mares. Reproduction. 2006;131(4):699-709. http://dx.doi.org/10.1530/rep.1.01011. PMid:16595721.

Ginther OJ, Gastal EL, Gastal MO. Spatial relationships between serrated granulosa and vascularity of the preovulatory follicle and developing corpus luteum. J Equine Vet Sci. 2007;27(1):20-7. http://dx.doi.org/10.1016/j.jevs.2006.11.012.

Grizendi BM, Fernandes CB. Éguas em idade avançada: perda embrionária relacionada à deficiência de progesterona e à doença endometrial. Rev Acad Ciênc Anim. 2015;13(1):23-9. http://dx.doi.org/10.7213/academica.13.FC.AO02.

Hwang YC, Limehouse JB. Atlas de acupuntura canina. In: Schoen AM, editor. Acupuntura veterinária: da arte antiga à moderna. São Paulo: ROCA; 2006. p. 122-146.

Köhne M, Kuhl J, Ille N, Erber R, Aurich C. Treatment with human chorionic gonadotrophin beforeovulation increases progestin concentration inearly equine pregnancies. Anim Reprod Sci. 2014;149(3-4):187-93. http://dx.doi.org/10.1016/j.anireprosci.2014.07.002. PMid:25096723. 
Luna SPL, Angeli AL, Ferreira CL, Lettry V, Scognamillo-Szabo M. Comparison of pharmacopuncture, aquapuncture and acepromazine for sedation of horses. Evid Based Complement Alternat Med. 2008;5(1):267-72. http://dx.doi.org/10.1093/ecam/nel096. PMid:18830446.

Mariante SA, Egito AA. Animal genetic resources in Brazil: Result of five centuries of natural selection. Theriogenology. 2002;57(1):223-35. http://dx.doi.org/10.1016/S0093-691X(01)00668-9. PMid:11775972.

Morel MCGD, Newcombe JR, Hayward K. Factors affecting pre-ovulatory follicle diameter in the mare: the effect of mare age, season and presence of other ovulatory follicles (multiple ovulation). Theriogenology. 2010;74(7):1241-7. http://dx.doi.org/10.1016/j.theriogenology.2010.05.027. PMid:20615543.

Nagy P, Huszenicza G, Reiczigel J, Juhász J, Kulcsár M, Abaváry K, Guillaume D. Factors affecting plasma progesterone concentration and the retrospective determination of time of ovulation in cyclic mares. Theriogenology. 2004;61(2-3):203-14. http://dx.doi.org/10.1016/S0093-691X(03)00211-5. PMid:14662122.

Quaresma M, Payan-Carreira R. Characterization of the estrous cycle of Asinina de Miranda jennies (Equus asinus). Theriogenology. 2015;83(4):616-24. http://dx.doi.org/10.1016/j.theriogenology.2014.10.021. PMid:25467767.

Rodrigues TG, Silva FS, Fagundes B, Estadual U, Fluminense N, Igua UN. Uso da eCG para formação do corpo lúteo eqüino e produção de progesterona. Acta Biomed Bras. 2014;5(1):56-70.

Romano RM, Ferreira JC, De Siqueira CH, Boakari YL, Ignácio FS, Novaes Filho LF, Thompson DL Jr, Meira C. Characterization of luteal blood flow and secretion of progesterone in mares treated with human chorionic gonadotropin for ovulation induction or during early diestrus. J Equine Vet Sci. 2015;35(7):591-7. http://dx.doi.org/10.1016/j.jevs.2015.03.196.

Samper JC. Induction of estrus and ovulation: why some mares respond and others do not. Theriogenology. 2008;70(3):445-7. http://dx.doi.org/10.1016/j.theriogenology.2008.04.040. PMid:18554709.

Sieme $\mathrm{H}$, Oldenho FH, Wolkers WF. Mode of action of cryoprotectants for sperm preservation. Anim Reprod Sci. 2016;169(1):2-5. http://dx.doi.org/10.1016/j.anireprosci.2016.02.004. PMid:26936658.

Souza DO, Araujo ML, Biscarde CEA, Mendes CS, Silva MAA, Romero DCM, Cardoso BM No, Santana ALA, Barbosa LP. Use of hormonal subdoses applied in Bai Hui acupuncture in estrus synchronization protocols for goats. Semina: Ciênc Agrár. 2019;40(4):1501-12. http://dx.doi.org/10.5433/16790359.2019v40n4p1501.

Taberner E, Medrano A, Peña A, Rigau T, Miró J. Oestrus cycle characteristics and prediction of ovulation in Catalonian jennies. Theriogenology. 2008;70(9):1489-97. http://dx.doi.org/10.1016/j.theriogenology.2008.06.096. PMid:18678401.

Tadesse G, Tefera M. Reproductive characteristics of abyssinian jennies exposed to stallions and jackasses. Ethiop Vet J. 2013;17(2):77-84. http://dx.doi.org/10.4314/evj.v17i2.6.

Wang XL, Zhang TF, Zhang HX, Mao HR, Huang GF. Therapeutic effects of acupoint injection at cervical Jiaji points and effects on ET and CGRP in the patient of ischemic stroke. Zhongguo Zhen Jiu. 2007;27(2):93-5. PMid:17370487.

Wilson CG, Downie CR, Hughes JP, Roser JF. Effects of repeated hCG injections on reproductive efficiency in mares. J Equine Vet Sci. 1990;10(4):301-8. http://dx.doi.org/10.1016/S0737-0806(06)80015-8.

Wynn SG, Luna SPL, Liu H, Xie H, Nan TC, Chien CH. Global acupuncture research: previously untranslated studies. Studies from Brazil. In: Schoen AM, editor. Veterinary acupuncture: ancient art to modern medicine. St Louis: Mosby; 2001. p. 53-7.

\section{Author contributions}

MOR: Conceptualization, Data curation, Formal Analysis, Investigation, Methodology, Project administration, Resources, Writing - original draft; RFB: Methodology, Supervision; MARF: Methodology, Supervision; ALAS: Conceptualization, Data curation, Formal Analysis, Methodology, Project administration, Resources, Writing - review \& editing; MAAS: Investigation, Methodology; MDF: Investigation, Methodology; LRS: Investigation, Methodology; LPB: Conceptualization, Data curation, Formal Analysis, Investigation, Methodology, Project administration, Resources, Supervision, Writing - review \& editing. 